\title{
Radium Isotopes as a Tracer of Water Sources and Mixing in the Vidourle Stream (South of France)
}

\section{Arnold Molina-Porras, Michel Condomines, Pierre-Louis Legeay, Vincent Bailly-Comte \& Jean Luc Seidel}

\section{Aquatic Geochemistry}

ISSN 1380-6165

Volume 26

Number 2

Aquat Geochem (2020) 26:119-136

DOI 10.1007/s10498-020-09371-1 
Your article is protected by copyright and all rights are held exclusively by Springer Nature B.V.. This e-offprint is for personal use only and shall not be self-archived in electronic repositories. If you wish to self-archive your article, please use the accepted manuscript version for posting on your own website. You may further deposit the accepted manuscript version in any repository, provided it is only made publicly available $\mathbf{1 2}$ months after official publication or later and provided acknowledgement is given to the original source of publication and a link is inserted to the published article on Springer's website. The link must be accompanied by the following text: "The final publication is available at link.springer.com". 


\title{
Radium Isotopes as a Tracer of Water Sources and Mixing in the Vidourle Stream (South of France)
}

\author{
Arnold Molina-Porras ${ }^{1,2,3}$ (D) Michel Condomines $^{2} \cdot$ Pierre-Louis Legeay $^{1}$. \\ Vincent Bailly-Comte ${ }^{4}$. Jean Luc Seidel ${ }^{1}$
}

Received: 20 October 2019 / Accepted: 27 February 2020 / Published online: 11 March 2020

(c) Springer Nature B.V. 2020

\begin{abstract}
This study reports analyses of Ra isotopes in a Mediterranean stream, the Vidourle river, whose upper course drains the granitic and metamorphic basement of the SE part of the French Massif Central (Cévennes) and then flows through the karstified carbonates of Jurassic and Cretaceous ages. In these low-Ra waters $\left({ }^{226} \mathrm{Ra}\right.$ activities range from 1.5 to $4.9 \mathrm{mBq} / \mathrm{L}$ ), all four Ra isotopes were successfully analyzed through gamma spectrometry during a single analysis. ${ }^{226} \mathrm{Ra}$ activities and $\left({ }^{228} \mathrm{Ra} /{ }^{226} \mathrm{Ra}\right)$ ratios are distinctly higher in waters draining the Variscan basement than in waters affected by dissolution of Mesozoic carbonates, in agreement with $\mathrm{U}$ contents and $\mathrm{Th} / \mathrm{U}$ ratios of both rock types. This results in a general N-S decrease, which parallels the evolution of the ${ }^{87} \mathrm{Sr} /{ }^{86} \mathrm{Sr}$ ratios. $\left({ }^{228} \mathrm{Ra} /{ }^{226} \mathrm{Ra}\right)$ ratios reported vs $1 /\left({ }^{226} \mathrm{Ra}\right)$ display linear relationships suggesting mixing of several water components related to the lithology. Ra might thus have a more conservative behavior than usually assumed, possibly because of the high water/rock ratio and flow rate in karst environment. Short-lived $\mathrm{Ra}$ isotopes $\left({ }^{224} \mathrm{Ra}\right.$ and $\left.{ }^{223} \mathrm{Ra}\right)$ are often in excess compared to their equilibrium values, due to their supply through alpha-recoil processes. ${ }^{223} \mathrm{Ra}$ activities in a Vidourle tributary can be explained by mixing of two water components, with a negligible radioactive decay of ${ }^{223} \mathrm{Ra}$ during underground water flow. The calculated minimum flow rates $(40-60 \mathrm{~m} / \mathrm{h})$ are in agreement with those deduced from artificial tracer experiments.
\end{abstract}

Keywords Radium isotopes in surface waters $\cdot{ }^{87} \mathrm{Sr} /{ }^{86} \mathrm{Sr}$ ratios $\cdot$ Water mixing and transit time $\cdot$ Upper Vidourle and Lez karst systems

Arnold Molina-Porras

arnold.molinaporras@ucr.ac.cr

1 HydroSciences, University of Montpellier, CNRS and IRD, 34090 Montpellier, France

2 Géosciences, University of Montpellier, CNRS, 34090 Montpellier, France

3 University of Costa Rica, 11501-2060 San José, Costa Rica

4 BRGM, NRE, University of Montpellier, 34090 Montpellier, France 


\section{Introduction}

$\mathrm{Ra}$ isotopes have long been used as geochemical tracers in water studies: surface or groundwaters in continental areas, coastal and oceanic waters. A range of applications of Ra isotopes in aquatic systems can be found in several reviews (e.g., Porcelli and Swarzenski 2003; Krishnaswami and Cochran 2008). One of the main applications concerns the process of submarine groundwater discharge (SGD), where Ra isotopes are used to trace the input of groundwater into coastal areas and constrain its flux and mixing proportion with marine waters, following the pioneering work of Moore (1996) (e.g., Lamontagne et al. 2015; Rodellas et al. 2017). This approach has also been applied to trace the influx of sinkhole vent waters in continental lakes (Baskaran et al. 2016).

In waters with a relatively high salinity (e.g., Sturchio et al. 1993; Elliot et al. 2014), $\mathrm{Ra}$ has a low affinity for particles, in contrast with its behavior in continental freshwaters, where $\mathrm{Ra}$ is assumed to be readily adsorbed onto mineral surfaces (especially onto clay minerals or Fe, Mn oxides/hydroxides; e.g., Krishnaswami et al. 1982; Porcelli et al. 2014). As a result, whereas the ratio of the long-lived Ra isotopes $\left({ }^{228} \mathrm{Ra} /{ }^{226} \mathrm{Ra}\right)$ can be used to trace water sources (e.g., Guerrero et al. 2016; Kraemer and Genereux 1998; Vinson et al. 2012, 2018), in a similar way as the ${ }^{87} \mathrm{Sr} /{ }^{86} \mathrm{Sr}$ ratio (e.g., Luís et al. 2019; Négrel et al. 1997; Shand et al. 2009), Ra activities can rarely provide the relative contributions of source waters (Chabaux et al. 2003). In some cases, however, Ra has been used to calculate the relative proportions of different surface waters (e.g., Kraemer 2005). Our previous study of the Lez karstic spring in the South of France (Molina-Porras et al. 2017b) has also shown that $\mathrm{Ra}$ can indeed behave as a conservative element over the relevant transport timescales.

In order to check the potential use for tracing water sources and mixing of both the longlived $\left({ }^{226} \mathrm{Ra}\right.$, in the ${ }^{238} \mathrm{U}$ decay series with a half-life $t_{1 / 2}$ of $1600 \mathrm{y}$, and ${ }^{228} \mathrm{Ra}$, in the ${ }^{232} \mathrm{Th}$ decay series, $\left.t_{1 / 2}=5.75 \mathrm{y}\right)$, and short-lived $\left({ }^{223} \mathrm{Ra}, t_{1 / 2}=11.4 \mathrm{~d}\right.$ in the ${ }^{235} \mathrm{U}$ decay series and ${ }^{224} \mathrm{Ra}, t_{1 / 2}=3.66 \mathrm{~d}$, in the ${ }^{232} \mathrm{Th}$ decay series) $\mathrm{Ra}$ isotopes, we have extended our previous study to another Mediterranean river, the Vidourle, flowing through a region of contrasted geology and hydrologic conditions (surface vs groundwater flow in a karstic network). The aim of this study was (1) to check the potential of the $\left({ }^{228} \mathrm{Ra} /{ }^{226} \mathrm{Ra}\right)$ ratios for distinguishing water sources from different rock reservoirs, and to test if these ratios, in conjunction with the ${ }^{226} \mathrm{Ra}$ activities, could be used to infer and quantify water mixing. (2) To compare the evolution of $\left({ }^{228} \mathrm{Ra} /{ }^{226} \mathrm{Ra}\right)$ ratios with ${ }^{87} \mathrm{Sr} /{ }^{86} \mathrm{Sr}$ ratios previously measured in earlier campaigns. And (3) to see if short-lived $\mathrm{Ra}$ isotopes $\left({ }^{223} \mathrm{Ra}\right.$ and/or $\left.{ }^{224} \mathrm{Ra}\right)$ could put constraints on water transfer time in the karst. Note that, throughout the paper, parentheses denote activities or activity ratios.

\section{Geological and Hydrogeological Contexts}

The studied area extends from the SE border of the French Massif Central (Cévennes), with granitic and metamorphic rocks (Cévennes granites and schists) of the Variscan basement. This basement is overlain to the South by southwards-dipping Mesozoic sediments extending from Trias to Lower Cretaceous. Numerous NE-SW faults affect the region, among them the "Cévennes fault-network" near Saint-Hippolyte-du-Fort (Fig. 1), and the "Les Matelles-Corconne" fault, further SE. These faults were already present during late 


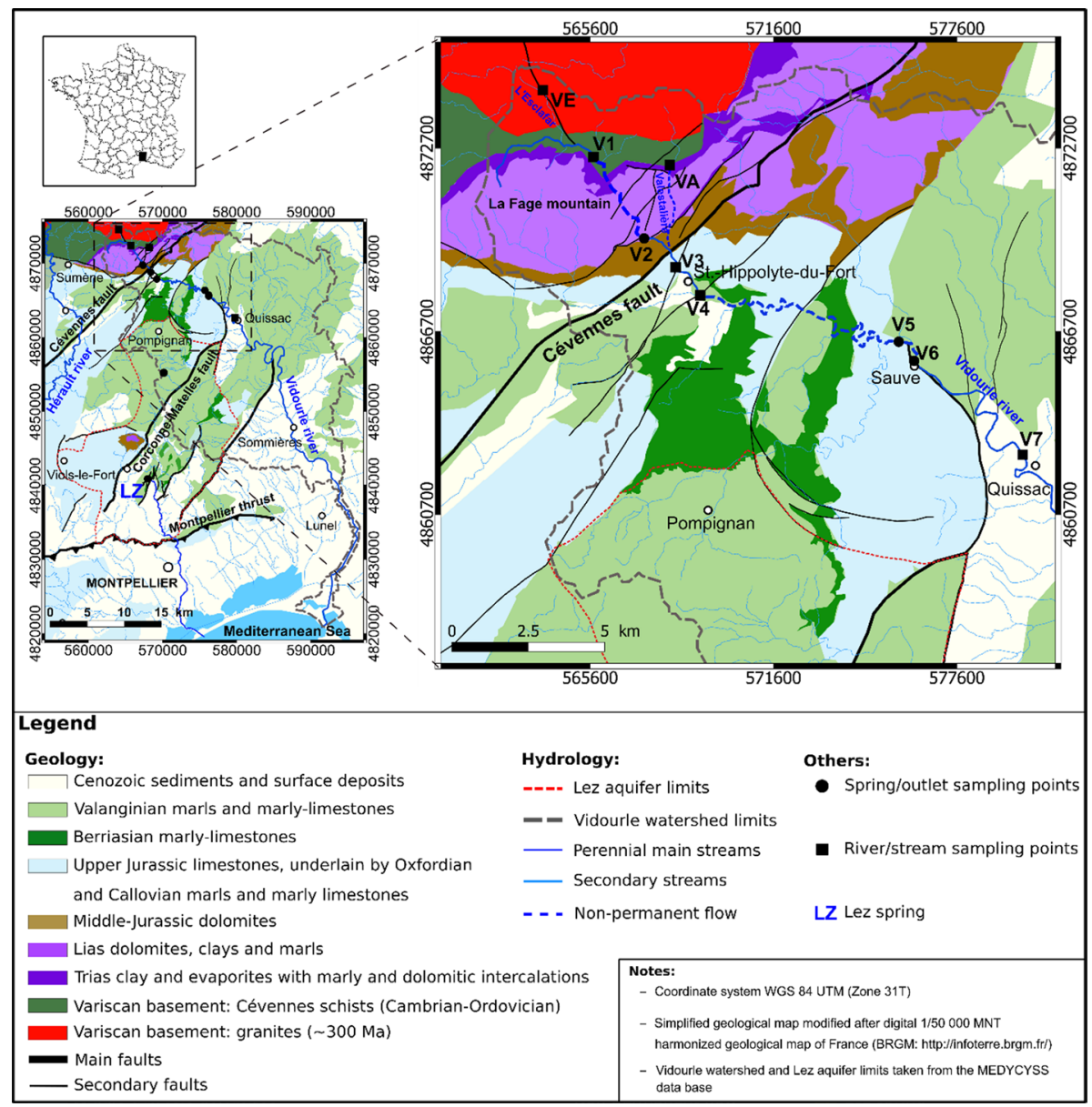

Fig. 1 Simplified geological map of the study area showing the main geological units and hydrological characteristics. The sampling point locations are reported along the Upper Vidourle course, and the Lez spring is indicated on the left map. (For a colored view of the figure, the reader is referred to the web version of this article)

Variscan times and controlled the evolution of the SE sedimentary Basin of France. They were reactivated during the Pyrenean orogeny (Upper Eocene), with left-lateral strikeslip displacements, and during the Oligocene extension as normal faults with downwards movements of the SE compartments. The studied part of the Vidourle watershed drains the whole geologic formations, from the Variscan basement to Mesozoic formations. Further South, the Vidourle hydrosystem shares a common watershed zone with the Lez hydrosystem, previously studied (Molina-Porras et al. 2017b). In this area, surface water feeds the Vidourle river, whereas water infiltrated at depth contributes to the Lez karst system.

The Vidourle river reaches the Mediterranean Sea, after a 95-km-long course (SANDRE 2012). Its whole watershed has an area of $800 \mathrm{~km}^{2}$. Only the upper course of the Vidourle river, upstream of the town of Quissac, has been investigated in this work. The Vidourle spring is located at $500 \mathrm{~m}$ a.s.1, on the northern slope of La Fage Mountain. This E-W elongated ridge exposes a part of the Mesozoic series, from Triassic formations at the base 
(sandstone, dolomitic layers and clays) lying unconformably on the Variscan basement to Liassic dolomites and siliceous limestones at the top (931 $\mathrm{m}$ a.s.1.). The north-western part of the watershed (left riverside of the Vidourle) corresponds to a non-karstic sub-watershed $\left(36 \mathrm{~km}^{2}\right)$, draining waters from fractured granitic and metamorphic rocks of the Variscan basement.

One of the main Vidourle tributaries in this zone is the Esclafar creek (VE in Fig. 1). During dry periods (low-water table), the surface flow of the Vidourle river is interrupted about $1.5 \mathrm{~km}$ downstream of the Cros bridge (V1), due to a sinkhole, when the river crosses a fault separating the Cévennes schists and karstified Liassic dolomites. The Vidourle resumes its surface flow at the Baumel spring (V2), around $2.5 \mathrm{~km}$ downstream (Drogue 1969). Between these points, the underground flow is through formations composed of Triassic evaporites and clays with dolomitic and marly intercalations, and Liassic limestones and dolomites. From the Baumel spring, the Vidourle river continues to flow at the surface until Saint-Hippolyte-du-Fort (V4). When it leaves this town, the Vidourle again flows underground for about $8 \mathrm{~km}$, due to another sinkhole/outlet system between Saint-Hippolyte-du-Fort (V4) and the Sauve spring (V6). Groundwater circulation in this zone is through a conduit system in massive and highly karstified limestones and marly limestones (Upper Jurassic and Lower Cretaceous). This groundwater circulation is the main recharge source (up to 65\%) of the Upper Vidourle karst aquifer (Vaute et al. 1997).

This karstic system is thus fed through both allogenic (via rapid transfer in the karst through the Saint Hippolyte-Sauve sinkhole/outlet system) and autogenic (via diffuse infiltration through the Sauve karstic area) recharge. Downstream of the Sauve spring, the Vidourle river keeps flowing at the surface until it reaches the Mediterranean Sea. One particular subsystem of the Vidourle upper-watershed is the Valestalière stream (Fig. 1), that rises in the granitic zone and, during low-water periods, takes an underground course, when it leaves the Cévennes schist zone (VA) and reaches the Liassic dolomites. The confluence of the Valestalière stream with the Vidourle river is $1 \mathrm{~km}$ downstream of the Baumel spring (near V3 in Fig. 1). However, during low-water periods, the Valestalière surface-discharge is negligible compared to the Vidourle flow rate.

\section{Sampling and Analytical Methods}

\subsection{Major Element Contents}

Temperature $\left( \pm 0.1{ }^{\circ} \mathrm{C}\right), \mathrm{pH}( \pm 0.1 \mathrm{pH}$ unit $)$ and electrical conductivity $( \pm 1.5 \%$, $\mathrm{T}_{\text {ref }}=25^{\circ} \mathrm{C}$ ) were measured directly in the field with a $\mathrm{pH}$ meter and a conductometer, both of the WTW 3210 series. Total alkalinity $\left( \pm 20 \mathrm{mg} / \mathrm{L}\right.$ or $\pm 0.33 \mathrm{mmol} / \mathrm{L} \mathrm{of}^{\mathrm{HCO}_{3}}{ }^{-}$) was measured by $\mathrm{HCl}$ titration with a G20 Compact Titrator (Mettler-Toledo). Major cations and anions were analyzed from $0.22 \mu \mathrm{m}$ filtered samples using a Dionex ${ }^{\mathrm{TM}}$ ICS 1000 ionic chromatography apparatus at HydroSciences Montpellier laboratory, with uncertainties of $2.4 \%$ for $\mathrm{Ca}^{2+}, 3.0 \%$ for $\mathrm{Mg}^{2+}, 2.5 \%$ for $\mathrm{Na}^{+}, 7.4 \%$ for $\mathrm{K}^{+}, 2.6 \%$ for $\mathrm{Cl}^{-}$and $4.4 \%$ for $\mathrm{SO}_{4}{ }^{2-}$. Saturation indexes were calculated with the Diagrammes software, version 6.48 (Simler 2014), using the Debye-Hückel approximation for the ion activity coefficient estimation. 


\subsection{Radium Isotopes}

Vidourle samples for Ra isotope analysis were taken, from May 2015 to March 2016, during low-water periods, when there is no water circulation in the Vidourle riverbed between V1 and V2, and from V4 to V6 (Fig. 1).

Radium sampling and measurement were performed as described in Molina-Porras et al. (2017a) using a portable sampling system. Ra was pre-concentrated from 100 to $300 \mathrm{~L}$ water samples directly in the field. Water was first pumped using a $12 \mathrm{~V}$ submersible pump (Comet Ocean ${ }^{\mathrm{TM}}$ ), filtered through $25 \mu \mathrm{m}$ and $5 \mu \mathrm{m}$ particle filters and poured into a $300 \mathrm{~L}$ graduated PE tank. The pump was then recovered and used to drive the water (at a flow rate less than $2 \mathrm{~L} / \mathrm{min}$ ) from the tank through an acrylic fiber cartridge and another cartridge filled with $6.5 \mathrm{~g}$ of Mn fiber (provided by Scientific Computer Instrument( $)$ ). Quantitative retention of Ra was previously checked by the analysis of a second Mn fiber inserted downstream of the first one. Back in the laboratory, the Mnfiber samples were dried overnight $\left(60-80{ }^{\circ} \mathrm{C}\right)$ and then reduced to ashes at $600{ }^{\circ} \mathrm{C}$ for $6 \mathrm{~h}$. The finely crushed Mn-oxide residues $(0.7-0.9 \mathrm{~g})$ were compacted in a polyethylene $(\mathrm{PE})$ tube for analysis in a CANBERRA ${ }^{\mathrm{TM}} \mathrm{Ge}$-well gamma detector, at Géosciences Montpellier laboratory.

The following gamma rays were used for the measurement of $\mathrm{Ra}$ isotopes: the $186.2 \mathrm{keV}$ ray for ${ }^{226} \mathrm{Ra}$, the $338.3 \mathrm{keV}$ and $911.2 \mathrm{keV}$ rays of ${ }^{228} \mathrm{Ac}$ for ${ }^{228} \mathrm{Ra}$, the $238.6 \mathrm{keV}$ ray of ${ }^{212} \mathrm{~Pb}$ and $583.2 \mathrm{keV}$ ray of ${ }^{208} \mathrm{Tl}$ for ${ }^{224} \mathrm{Ra}$, the composite peak around $270 \mathrm{keV}$ (269.5 keV ray of ${ }^{223} \mathrm{Ra}$ and $271.2 \mathrm{keV}$ ray of ${ }^{219} \mathrm{Rn}$ ) for ${ }^{223} \mathrm{Ra}$. Ra isotope activities were calculated by comparison with in-house standards that were prepared from 0.7 to $0.9 \mathrm{~g}$ of Mn-oxide powders, obtained by ashing of virgin Mn fiber. The Mnoxide powders were poured into PE tubes and impregnated with $\mathrm{U}$ or Th solutions of known activities and both in secular radioactive equilibrium, then dried and compacted to obtain the same geometry as that of the samples. Details on the procedure and calculations, including decay and interference corrections, are described in Molina-Porras et al. (2017a) and Condomines et al. (2010).

The typical relative standard combined uncertainties $(1 \sigma)$ for these analyses were $2-3 \%$ for ${ }^{226} \mathrm{Ra},{ }^{228} \mathrm{Ra}$ and ${ }^{224} \mathrm{Ra}$; and less than $10 \%$ for ${ }^{223} \mathrm{Ra}$. While early determinations through gamma spectrometry of $\mathrm{Ra}$ isotopes extracted from large volumes of water often required an independent measurement of the ${ }^{226} \mathrm{Ra}$ activity (Baskaran et al. 1993), the quantitative extraction of Ra with our procedure (Molina Porras et al. 2017a) allowed measurement of the activities of all $\mathrm{Ra}$ isotopes in a single analysis.

\subsection{Strontium Isotopes}

Vidourle waters analyzed for $\mathrm{Sr}$ isotopes were sampled from October 2008 to May 2013, during various hydrological conditions. $60 \mathrm{~mL}$ of water was filtered to $0.22 \mu \mathrm{m}$, and $\mathrm{Sr}$ was separated using standard ion exchange procedures. For samples analyzed before 2013, measurements of ${ }^{87} \mathrm{Sr} /{ }^{86} \mathrm{Sr}$ ratios were carried out using a thermal ionization mass spectrometer (TIMS) at Geosciences laboratory, Rennes, France. The average value of the NBS 987 standard was $0.710262 \pm 0.000013$. For 2013 samples, measurements of ${ }^{87} \mathrm{Sr} /{ }^{86} \mathrm{Sr}$ ratios were carried out by TIMS, with an average relative uncertainty of $0.02 \%$, at the Service d'Analyse des Roches et des Minéraux (SARM) of the Centre de Recherches Pétrographiques et Géochimiques (CRPG) in Nancy, France. 


\section{Results and Discussion}

Chemical composition and physical parameters of the sampled waters are reported in Table 1, and $\mathrm{Ra}$ isotope activities and activity ratios in Table 2 . In both tables, samples are listed according to their location along the Vidourle river, from the closest to the spring to the farthest downstream (VE to V7). The samples were separated into groups corresponding to the lithology of the watershed rocks. Sampling points VE (granites) and VA (granites and schists) are considered as representative of waters draining the Variscan basement, while samples of the Vidourle river at Cros (V1) correspond to a mixing of waters of the Variscan basement and Triassic and Liassic rocks from the northern flank of La Fage mountain. V2, V3 and V4 samples are considered as part of Saint-Hippolytedu-Fort waters, corresponding to waters draining Triassic and Liassic terranes (mainly in the Hettangian dolomitic karst), but also influenced by Cros waters, which have infiltrated upstream. V5, V6 and V7 samples represent waters having flowed through the Upper Vidourle karstic systems.

For comparison, we have also reported in Tables 1 and 2 the compositions and Ra activities of the main types of Lez spring waters. These waters were classified as diluted (DW), low (LW) and mineralized waters (MW), corresponding to waters diluted by surface water after heavy rain episodes, waters sampled during low-waters periods and mineralized waters of deep origin, respectively, (Molina-Porras et al. 2017b). The reported values are average values for each type of water.

\subsection{Chemical Composition of Waters}

In general, electrical conductivity (EC) values of the Vidourle waters $(78-607 \mu \mathrm{S} / \mathrm{cm})$ are systematically lower than the waters of the Lez spring $(680-890 \mu \mathrm{S} / \mathrm{cm})$, due to their lower contents of $\mathrm{Ca}, \mathrm{Na}, \mathrm{HCO}_{3}$ and $\mathrm{Cl}$. Major element compositions clearly distinguish waters flowing through the granitic and metamorphic basement (with relatively high $\mathrm{Na} / \mathrm{Ca}$ molar ratios) from those flowing through Mesozoic carbonate rocks (with lower $\mathrm{Na} / \mathrm{Ca}$ ratios). This can be illustrated in a $\mathrm{Mg} / \mathrm{Ca}-\mathrm{Na} / \mathrm{Ca}$ diagram (Fig. 2). Additional data from Legeay (2013) extend the range of water compositions to a full hydrologic year. Roughly, two mixing trends are apparent for the Vidourle system: one between a "granitic" water component (G in Fig. 2) and a "carbonate" water component represented by the Baumel spring (V2, water from the Liassic dolomites and limestones, with relatively high $\mathrm{Mg} / \mathrm{Ca}$ ratios), the other between the mixed St Hippolyte water (V6) and a component typical of Upper Jurassic/Lower Cretaceous limestones ( $\mathrm{J}+\mathrm{C}$ in Fig. 2, with low $\mathrm{Na} / \mathrm{Ca}$ and $\mathrm{Mg} / \mathrm{Ca}$ ratios). The latter is the main water mass feeding the karstic systems further South, such as that of the Lez aquifer. The Lez waters themselves define a third mixing trend in Fig. 2 between this $\mathrm{J}+\mathrm{C}$ component and a deep mineralized component D (Molina-Porras et al. 2017b). This latter component is assumed to be best represented by a highly mineralized water found at a depth of around $900 \mathrm{~m}$ in a borehole reaching Middle Jurassic carbonates in Montpellier, about $13 \mathrm{~km}$ South of the Lez spring (Batiot-Guilhe et al. 2013). It could derive from paleo-seawaters, which flooded the deep Mesozoic karst during the transgression following the Messinian crisis and interacted with Middle Jurassic carbonates.

Water draining the Variscan basement are undersaturated with respect to calcite, whereas all other waters affected by carbonate dissolution are close to saturation (V2 and V6) or clearly over-saturated. This is particularly true for surface samples that have 


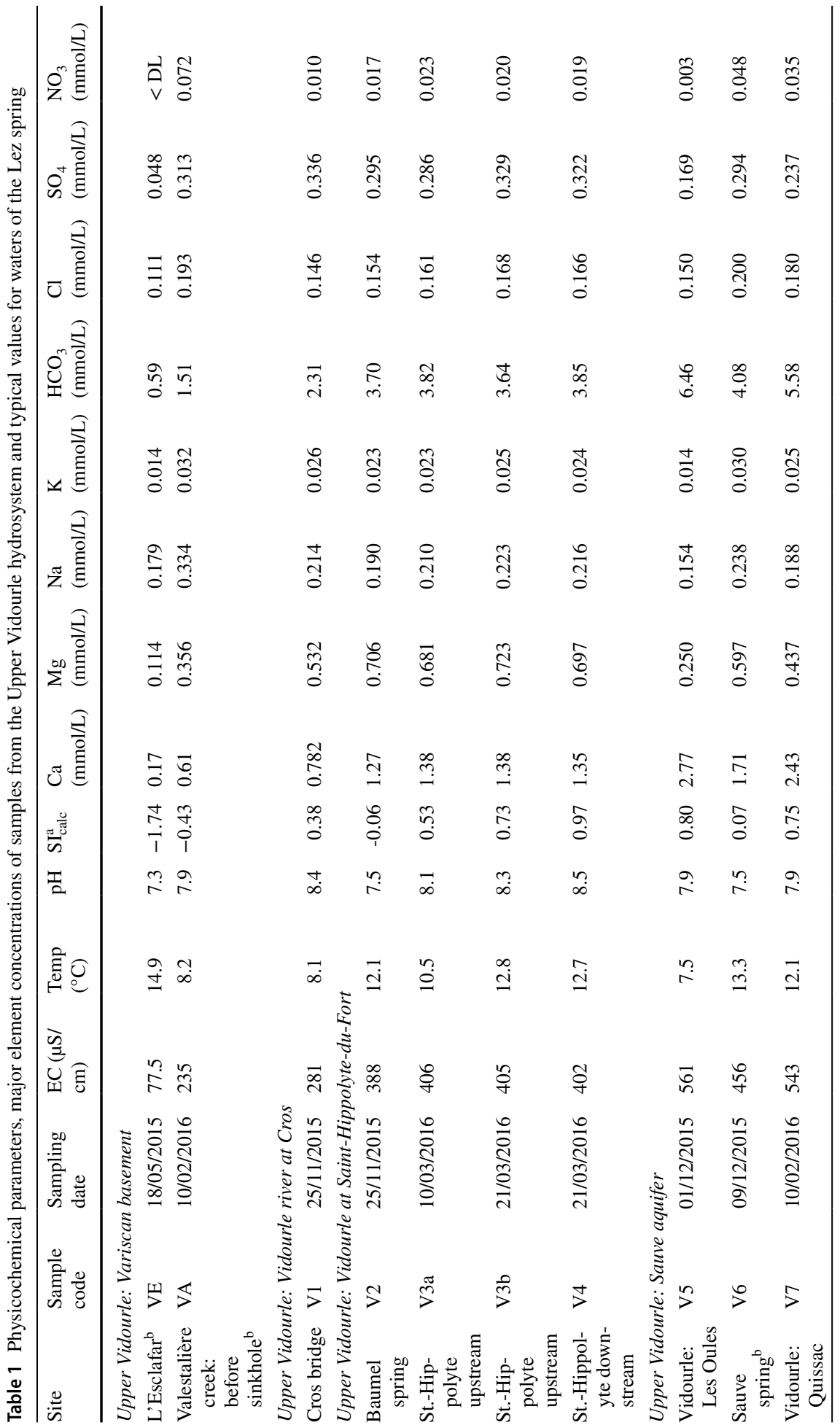




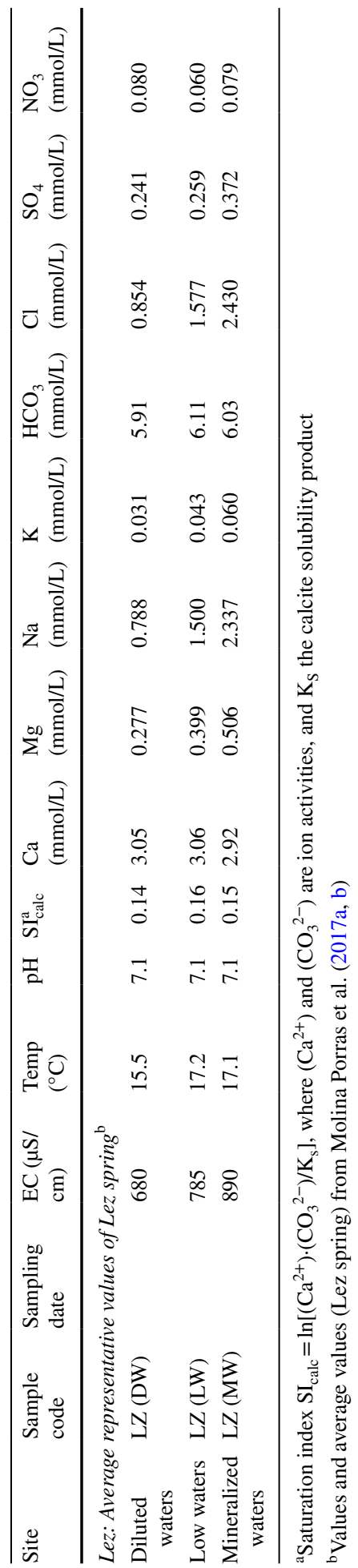




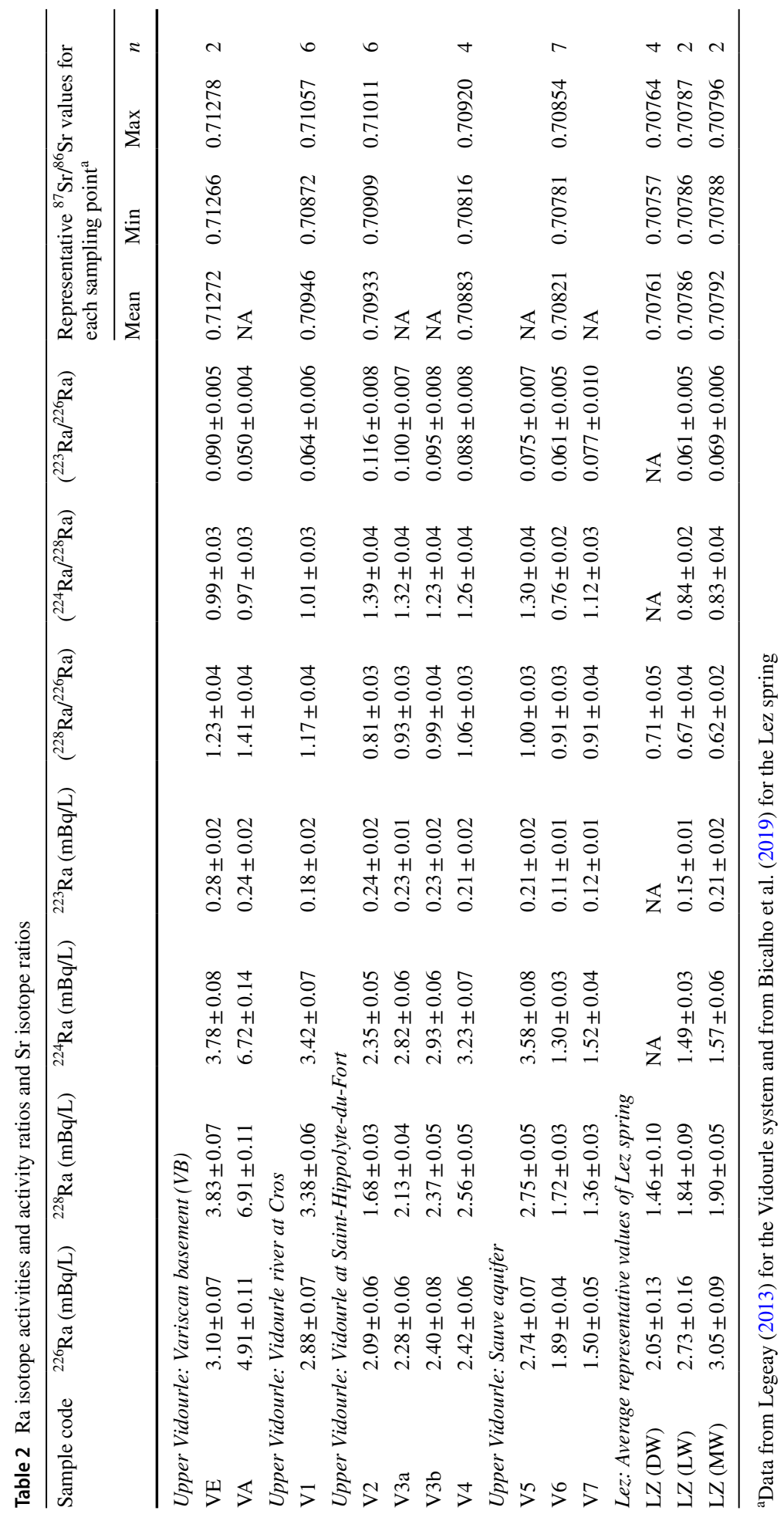




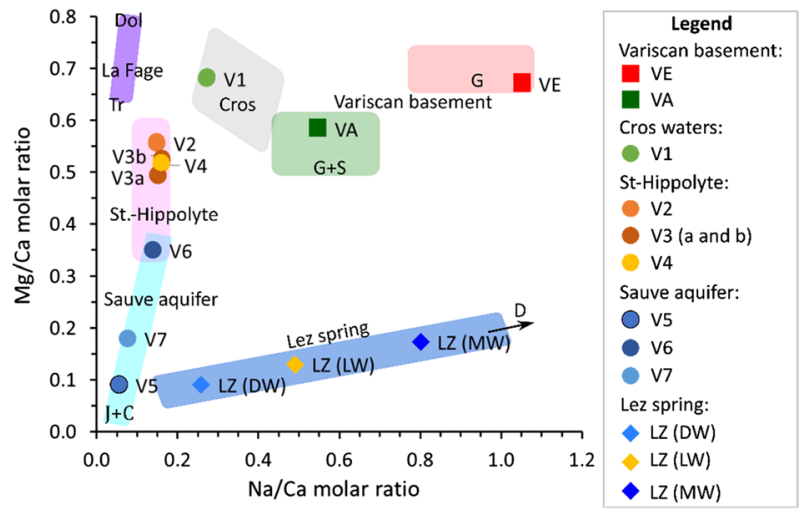

Fig. $2 \mathrm{Mg} / \mathrm{Ca}$ vs $\mathrm{Na} / \mathrm{Ca}$ molar ratios of samples in Table 1, showing some typical values of waters from different geological reservoirs. Typical values for the Upper Vidourle hydrosystem are taken from Legeay unpublished data (2013): waters draining granites (red field), granites and schists (green field), waters sampled at Cros (gray field), Saint-Hippolyte-du-Fort (pink field), from the Sauve aquifer (light blue field) and from La Fage Mountain (violet field). Values for the Lez spring (blue field) are taken from Batiot-Guilhe et al. (2013) and Molina Porras et al. (2017b). These fields are both related to the sampling area and to the lithology of the drained rocks. Additional indications: waters draining $\mathrm{G}$ (granite), $\mathrm{G}+\mathrm{S}$ (granite and Cévennes schist), Tr (Triassic evaporites), Dol (Liassic dolomite), J + C (Jurassic and Cretaceous limestones). D represents the deep mineralized water component of the Lez spring. (For a colored view of the figure, the reader is referred to the web version of this article, same symbols in Figs. 2, 3, 4,5)

degassed part of their dissolved $\mathrm{CO}_{2}$, as indicated by their high $\mathrm{pH}$, as in St Hippolyte samples (V3 and V4).

\section{2 ${ }^{226} \mathrm{Ra}$ Activities and $\left({ }^{228} \mathrm{Ra} /{ }^{226} \mathrm{Ra}\right)$ Ratios}

Both ${ }^{226} \mathrm{Ra}$ activity and $\left({ }^{228} \mathrm{Ra} /{ }^{226} \mathrm{Ra}\right)$ ratio in water primarily depend on the $\mathrm{U}$ content and $\mathrm{Th} / \mathrm{U}$ ratio of the source rock. $\mathrm{U}$ contents and $\mathrm{Th} / \mathrm{U}$ ratios are usually higher in magmatic rocks, and in detrital sedimentary rocks derived from their erosion, than in carbonate rocks. Indeed, Th and $U$ are both magmaphile (lithophile) elements, which are concentrated in the residual melt during magmatic differentiation (Adams et al. 1959). Their concentrations are thus high in the silicic granitic melts. The $\left({ }^{228} \mathrm{Ra} /{ }^{226} \mathrm{Ra}\right)$ ratio is also high in a granitic rock in radioactive equilibrium, since it is equal to the $\left({ }^{232} \mathrm{Th} /{ }^{238} \mathrm{U}\right)$ ratio. It should be noted, however, that the $\left({ }^{228} \mathrm{Ra} /{ }^{226} \mathrm{Ra}\right)$ ratio might not represent exactly the $\mathrm{Th} / \mathrm{U}$ ratio of the whole rock, since rock dissolution is an incongruent process, because of different dissolution rates of the various minerals present in granitic or metamorphic rocks. But Th and $\mathrm{U}$ have very different properties in aqueous environments. While Th is highly insoluble, $\mathrm{U}$ in its oxidized form $\mathrm{U}^{\mathrm{VI}}$ is very soluble, especially in $\mathrm{HCO}_{3}$-rich waters such as seawater (e.g., Chen et al. 1986). Thus, rocks that result from chemical precipitation in water, like carbonates, do contain significant concentrations of $U$, and very little $\mathrm{Th}$ (low Th/U ratios). One can thus expect that the water $\left({ }^{228} \mathrm{Ra} /{ }^{226} \mathrm{Ra}\right)$ ratios will decrease when carbonate dissolution becomes significant.

This is indeed what is roughly observed when the water flows downstream along the Vidourle course (Table 2). ${ }^{226} \mathrm{Ra}$ activities and $\left({ }^{228} \mathrm{Ra} /{ }^{226} \mathrm{Ra}\right)$ ratios decrease from 3.1 to $4.9 \mathrm{mBq} / \mathrm{L}$ and 1.23-1.41, respectively, in waters of the Variscan basement, to $1.5 \mathrm{mBq} / \mathrm{L}$ and 0.91 downstream at Quissac, after the Vidourle flowed through the Sauve karstic 
aquifer. This evolution parallels that of major elements, with an increase in $\mathrm{Ca}$ and $\mathrm{HCO}_{3}$ contents and a decrease in $\mathrm{Na} / \mathrm{Ca}$ and $\mathrm{Mg} / \mathrm{Ca}$ ratios (Fig. 2). However, the decrease in ${ }^{226} \mathrm{Ra}$ activity and $\left({ }^{228} \mathrm{Ra} /{ }^{226} \mathrm{Ra}\right)$ ratios is not uniform along the Vidourle course. For example, between Baumel (V2) and Saint-Hippolyte-du-Fort (V3), the $\left({ }^{228} \mathrm{Ra} /{ }^{226} \mathrm{Ra}\right)$ ratio increases from 0.81 to 1.06. As discussed later in Sect. 4.4, we attribute this evolution to the influence of basement water brought to the Vidourle by the underground flow of the Valestalière stream, its tributary on the left bank (VA water). Another example is the case of Les Oules outlet (V5, Table 2), which has higher $\left({ }^{226} \mathrm{Ra}\right)$ activity and $\left({ }^{228} \mathrm{Ra} /{ }^{226} \mathrm{Ra}\right)$ ratio $(2.74 \mathrm{mBq} / \mathrm{L}$ and 1.00, respectively), compared to the nearby Sauve spring (V6). The water emerging at Les Oules outlet comes mainly from the infiltration of waters of the Crespenou, a small tributary of the Vidourle, which drains Triassic, Jurassic and Cretaceous formations and has a different chemical composition (Drogue 1969) compared to Sauve spring. This outlet, however, has a negligible contribution to the chemistry of the main Vidourle river, because of its very low flow rate compared to the Sauve spring (Drogue 1969).

$\left({ }^{228} \mathrm{Ra} /{ }^{226} \mathrm{Ra}\right)$ activity ratios are reported in Fig. 3 versus $1 /\left({ }^{226} \mathrm{Ra}\right)$, a classical diagram in which mixing is represented by straight lines. Our data clearly define a linear trend between the "crystalline basement" water component and the Baumel water component. The Sauve and Quissac water samples deviate from this trend; they extend from the St Hippolyte waters and point toward a component with low $\left({ }^{226} \mathrm{Ra}\right)$ activity and relatively lower $\left({ }^{228} \mathrm{Ra} /{ }^{226} \mathrm{Ra}\right)$ ratio. As a reference, the composite water component from the Upper Jurassic/Lower Cretaceous limestones, as identified from the Lez spring data (see Fig. 4b in Molina-Porras et al. 2017b), is reported in the diagram. This component could indeed be representative of the aquifers located in the Mesozoic limestones. It should be emphasized that the $\left({ }^{228} \mathrm{Ra} /{ }^{226} \mathrm{Ra}\right.$ ) ratio of this component, close to 0.90 , is much higher than expected for a pure limestone (e.g., $\leq 0.3$, Gascoyne 1992): This value has been explained by a significant contribution of Ra from alterites, with high $\mathrm{Th} / \mathrm{U}$ ratios, filling the Mesozoic karst (Molina-Porras et al. 2017b). The end-members identified in Fig. 3 are similar to those derived from the plot of Fig. 2, based on major elements. For reference, the field of the Lez spring data (Molina-Porras et al. 2017b) is also reported in Fig. 3. ${ }^{226}$ Ra activities and

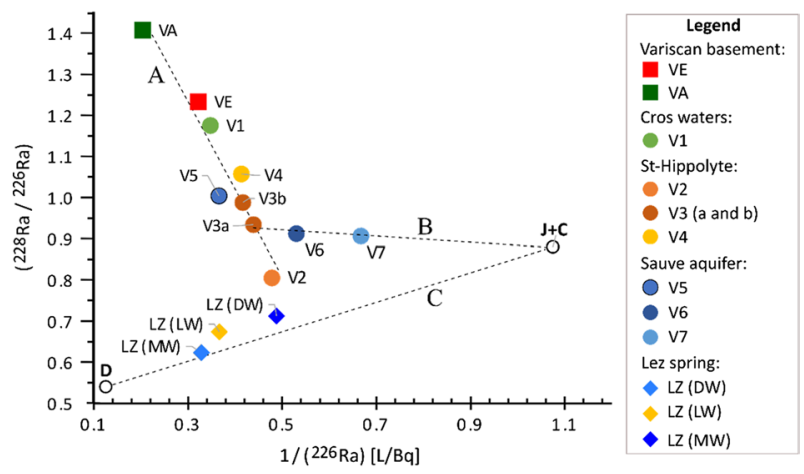

Fig. 3 Variation of $\left({ }^{228} \mathrm{Ra} /{ }^{226} \mathrm{Ra}\right)$ with $1 /\left({ }^{226} \mathrm{Ra}\right)$ of samples in Table 2, suggesting two mixing processes in the Vidourle waters between (i) the Variscan basement (VA) and Baumel (V2) waters (dashed line A), and (ii) the Saint Hippolyte-du-Fort waters (V3, V4) and typical karstic Jurassic/Cretaceous waters (J +C component, as defined by Molina-Porras et al. 2017b) (dashed line B). The Lez data define a third mixing trend (dashed line C) between this J + C component and a "deep" water end-member D (Molina Porras et al. 2017b). See text for further explanation. (For a colored view of the figure, the reader is referred to the web version of this article, same symbols in Figs. 2, 3, 4, 5) 

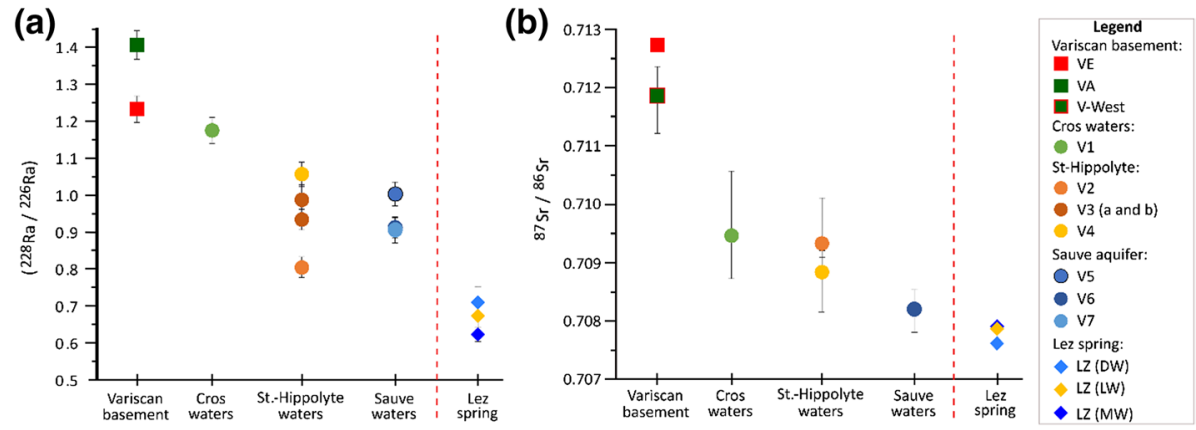

Fig. 4 Geographical variation of $\mathbf{a}\left({ }^{228} \mathrm{Ra} /{ }^{226} \mathrm{Ra}\right)$ ratios and $\mathbf{b}{ }^{87} \mathrm{Sr} /{ }^{86} \mathrm{Sr}$ ratios in the Upper Vidourle and Lez hydrosystems. Note that the error bars for $\left({ }^{228} \mathrm{Ra} /{ }^{226} \mathrm{Ra}\right)$ ratios correspond to the analytical uncertainties, while the bars for ${ }^{87} \mathrm{Sr} /{ }^{86} \mathrm{Sr}$ ratios indicate the range of ${ }^{87} \mathrm{Sr} /{ }^{86} \mathrm{Sr}$ values measured at different dates at the same sampling site (Table 2). The two parallel trends of decreasing isotope ratios downstream illustrate the increasing influence of carbonate dissolution. The dashed line separates the Vidourle and Lez hydrosystems. (For a colored view of the figure, the reader is referred to the web version of this article, same symbols in Figs. 2, 3, 4, 5)

$\left({ }^{228} \mathrm{Ra} /{ }^{226} \mathrm{Ra}\right)$ ratios in the Lez spring waters range from 2 to $3 \mathrm{mBq} / \mathrm{L}$ and 0.71 to 0.62 , respectively. Its field extends toward higher Ra activities and lower $\left({ }^{228} \mathrm{Ra} /{ }^{226} \mathrm{Ra}\right)$ ratios, far away from the Jurassic/Cretaceous carbonate component, because of the participation of the deep mineralized component, previously described in Sect. 4.1, strongly enriched in ${ }^{226} \mathrm{Ra}$ and with a low $\left({ }^{228} \mathrm{Ra} /{ }^{226} \mathrm{Ra}\right.$ ) ratio (Molina-Porras et al. 2017b). This results in a positive correlation between Ra activity and conductivity in the Lez spring waters, whereas the Vidourle waters display a negative correlation, due to the relative contribution of granitic and carbonate waters.

The diagram of Fig. 3 suggests that ${ }^{228} \mathrm{Ra}$ and ${ }^{226} \mathrm{Ra}$ behave relatively conservatively in the Vidourle system, and that Ra can be used to infer mixing proportions of water masses with different $\left({ }^{228} \mathrm{Ra} /{ }^{226} \mathrm{Ra}\right)$ ratios. For example, the Vidourle water at Quissac (V7) can be considered as a mixture of $43 \%$ of water of the Upper Vidourle course near St Hippolyte (V3a), and $57 \%$ of water derived from the Jurassic/Cretaceous karst. Such a quantitative approach is further discussed in Sect. 4.4 and applied to the case of mixing of the Valestalière waters with those of the Vidourle, downstream from the Baumel spring, i.e., in the St Hippolyte area.

The apparent nearly conservative behavior of ${ }^{228} \mathrm{Ra}$ and ${ }^{226} \mathrm{Ra}$ in the studied freshwater environment might seem surprising in view of the commonly held view of a quick Ra adsorption onto mineral surfaces (e.g., Krishnaswami et al. 1982). However, adsorption depends on many parameters such as the water/rock ratio (i.e., the porosity), the water velocity, the nature and surface area of the minerals in contact with water, and chemical and physical parameters ( $\mathrm{pH}$, Eh, major ions), with the possible influence of complexes. Without additional data (e.g., experimental), a detailed discussion is precluded. We can simply emphasize that, in well-established karst systems, the water/rock ratio and the water velocity are high, clay minerals are of relatively minor importance, and that these conditions make $\mathrm{Ra}$ adsorption less likely than in low-porosity media for example. 


\subsection{Regional Variation of $\left({ }^{228} \mathrm{Ra} /{ }^{226} \mathrm{Ra}\right)$ and ${ }^{87} \mathrm{Sr} /{ }^{86} \mathrm{Sr}$ Ratios}

${ }^{87} \mathrm{Sr} /{ }^{86} \mathrm{Sr}$ ratios were measured in the Vidourle hydrosystem and Lez spring during previous sampling campaigns (Bicalho et al. 2019; Legeay 2013). Their average values and ranges at each sampling point are reported in Table 2, and their spatial variation in Fig. 4b. A general decrease in these ratios is noticeable from the Upper Vidourle course to the Lez spring, which mimics the evolution of the $\left({ }^{228} \mathrm{Ra} /{ }^{226} \mathrm{Ra}\right)$ ratios shown in Fig. 4a.

The samples of the Variscan basement (VE) have the highest ${ }^{87} \mathrm{Sr} /{ }^{86} \mathrm{Sr}$ values $(0.7127$ for VE), while the lowest values correspond to the Lez spring water draining the Jurassic and Cretaceous formations. Silicic magmatic and metamorphic rocks of the upper crust have high $\mathrm{Rb} / \mathrm{Sr}$ ratios, and decay of ${ }^{87} \mathrm{Rb}$ results in high ${ }^{87} \mathrm{Sr} /{ }^{86} \mathrm{Sr}$ ratios. As for the $\left({ }^{228} \mathrm{Ra} /{ }^{226} \mathrm{Ra}\right)$ ratio, the ${ }^{87} \mathrm{Sr} /{ }^{86} \mathrm{Sr}$ ratio measured in water does not necessarily represent the ratio of the whole rock, because of the different dissolution rates of mineral phases. For example, preferential dissolution of biotite which has a high ${ }^{87} \mathrm{Sr} /{ }^{86} \mathrm{Sr}$ ratio in a granite (higher than the ratio of the whole rock, dominated by the ${ }^{87} \mathrm{Sr} /{ }^{86} \mathrm{Sr}$ ratio of the Sr-rich plagioclase) can lead to a $\mathrm{Sr}$ isotope ratio in water higher than that of the whole rock (Blum et al. 1993). In contrast, the ${ }^{87} \mathrm{Sr} /{ }^{86} \mathrm{Sr}$ ratio of marine carbonates represents the seawater ratio and is lower than the ratio of the upper crust. The present seawater value is 0.7092 (Farrell et al. 1995), but this ratio has been lower during most of the Phanerozoic, with large fluctuations reflecting the variable respective contributions of continental erosion, leading to high ${ }^{87} \mathrm{Sr} /{ }^{86} \mathrm{Sr}$ ratios, and oceanic crust alteration leading to low ${ }^{87} \mathrm{Sr} /{ }^{86} \mathrm{Sr}$ ratios. Seawater ${ }^{87} \mathrm{Sr} /{ }^{86} \mathrm{Sr}$ ratios were the lowest at the beginning of the Upper Jurassic (0.7068) and, during Lower Cretaceous, remained lower than 0.7075 (Jones et al. 1994), a value close to the ratios measured in the Lez waters (0.7076-0.7079).

However, waters from the Sauve spring that have transited through the same Upper Jurassic/Lower Cretaceous karst reservoir as the Lez waters display $\left({ }^{228} \mathrm{Ra} /{ }^{226} \mathrm{Ra}\right)$ and ${ }^{87} \mathrm{Sr} /{ }^{86} \mathrm{Sr}$ ratios that are both higher $(0.91$ and up to 0.7085 , respectively) than typical values of the Lez karst spring (Table 2). These data confirm the significant contribution in the Sauve spring of water derived from the upper non-karstic Vidourle river, with higher $\left({ }^{228} \mathrm{Ra} /{ }^{226} \mathrm{Ra}\right)$ and ${ }^{87} \mathrm{Sr} /{ }^{86} \mathrm{Sr}$ ratios, in agreement with previous studies (Drogue 1969; Vaute et al. 1997).

Thus, the general evolution of ${ }^{87} \mathrm{Sr} /{ }^{86} \mathrm{Sr}$ ratios shown in Fig. $4 \mathrm{~b}$ reflects the transition from waters dominated by interaction with the Variscan basement (Upper Vidourle river) to waters dominated by dissolution of Mesozoic carbonates. The roughly parallel evolution of $\left({ }^{228} \mathrm{Ra} /{ }^{226} \mathrm{Ra}\right)$ and ${ }^{87} \mathrm{Sr} /{ }^{86} \mathrm{Sr}$ ratios displayed in Fig. 4a, b is simply a consequence of the similar behavior of the $\mathrm{Th} / \mathrm{U}$ and $\mathrm{Rb} / \mathrm{Sr}$ ratios in the two main components implied in water-rock interactions: the igneous and metamorphic rocks with high $\mathrm{Rb} / \mathrm{Sr}$ and $\mathrm{Th} / \mathrm{U}$ ratios, and carbonates with low $\mathrm{Th} / \mathrm{U}$ and $\mathrm{Rb} / \mathrm{Sr}$ ratios.

\subsection{Short-Lived Ra Isotopes}

The $\left({ }^{224} \mathrm{Ra} /{ }^{228} \mathrm{Ra}\right)$ and $\left({ }^{223} \mathrm{Ra} /{ }^{226} \mathrm{Ra}\right)$ ratios involving the two short-lived $\mathrm{Ra}$ isotopes do not show the same regular evolution as the $\left({ }^{228} \mathrm{Ra} /{ }^{226} \mathrm{Ra}\right)$ ratios (Table 2). Indeed, while the $\left({ }^{224} \mathrm{Ra} /{ }^{228} \mathrm{Ra}\right)$ ratios are close to the equilibrium value of 1 in waters from the Upper Vidourle course, they increase in the Saint-Hippolyte-du-Fort area (1.23 to 1.49). A value significantly lower than 1 is found at the Sauve spring (0.76), while this ratio is 0.84 in the Lez karst spring. $\left({ }^{223} \mathrm{Ra} /{ }^{226} \mathrm{Ra}\right)$ ratios are systematically higher than the expected value at 
equilibrium (0.046, corresponding to the natural $\left({ }^{235} \mathrm{U} /{ }^{238} \mathrm{U}\right)$ ratio). While long-lived $\mathrm{Ra}$ isotopes are mostly influenced by rock dissolution, the short-lived $\mathrm{Ra}$ isotopes are also introduced into water by alpha-recoil processes (e.g., Krishnaswami et al. 1982; Porcelli 2008). Moreover, their activities can be significantly modified by decay if the water transfer times are of the order of days. Interpreting ${ }^{224} \mathrm{Ra}$ data is further complicated by the fact that its grandparent ${ }^{228} \mathrm{Ra}$ is present in water, whereas its direct parent ${ }^{228} \mathrm{Th}$ is assumed to be quickly adsorbed onto suspended particles or the conduit walls. ${ }^{223} \mathrm{Ra}$ has no highly soluble ascendant in the decay chain and is potentially easier to interpret. It may be significant, however, that both $\left({ }^{224} \mathrm{Ra} /{ }^{228} \mathrm{Ra}\right)$ and $\left({ }^{223} \mathrm{Ra} /{ }^{226} \mathrm{Ra}\right)$ ratios have their highest values $(1.39$ and 0.116 , respectively), in waters of the Baumel spring, which corresponds to the Vidourle resurgence after its underground flow in the Hettangian dolomite karstic reservoir. This suggests that both ${ }^{224} \mathrm{Ra}$ and ${ }^{223} \mathrm{Ra}$ might be introduced into water by alpha-recoil processes operating in a porous reservoir (e.g., alluvial sand infillings, in the Baumel Hettangian karstic aquifer) with a low-water/rock ratio (Porcelli and Swarzenski 2003). In this respect, the presence in surface stream water of ${ }^{224} \mathrm{Ra}$ and ${ }^{223} \mathrm{Ra}$ in excess of their equilibrium values is a good indicator of groundwater influx, in the same way as ${ }^{222} \mathrm{Rn} .{ }^{222} \mathrm{Rn}$ is commonly used to trace groundwater influx because it is never particle reactive. But it can be efficiently degassed in surface waters, and the Rn signal might disappear rather quickly downstream. For example, the Baumel spring has a relatively high ${ }^{222} \mathrm{Rn}$ activity of $8.1 \mathrm{~Bq} / \mathrm{L}$, but its activity falls to $0.8-0.6 \mathrm{~Bq} / \mathrm{L}$ near St Hippolyte (Molina-Porras, unpublished results).

The activities of all $\mathrm{Ra}$ isotopes are lower in the Sauve spring than in the waters of the Vidourle upper course at St Hippolyte and upstream. This is primarily due to the contribution to this spring of the Sauve karstic aquifer in the Upper Jurassic/Lower Cretaceous carbonates. But the low $\left({ }^{224} \mathrm{Ra} /{ }^{228} \mathrm{Ra}\right.$ ) ratio of 0.76 (the only one less than 1 in the Vidourle waters) and the $\left({ }^{223} \mathrm{Ra} /{ }^{226} \mathrm{Ra}\right.$ ) ratio of 0.061 , lower than those measured at St Hippolyte (Table 2), might in part reflect a relatively long transit time (several days) of the Sauve spring waters in their underground course, with significant decay of both ${ }^{224} \mathrm{Ra}$ and ${ }^{223} \mathrm{Ra}$. Note that ${ }^{224} \mathrm{Ra}$ will decrease more rapidly than ${ }^{223} \mathrm{Ra}$ because of its shorter half-life.

The evolution of the $\left({ }^{223} \mathrm{Ra} /{ }^{226} \mathrm{Ra}\right)$ and $\left({ }^{228} \mathrm{Ra} /{ }^{226} \mathrm{Ra}\right)$ ratios between the Baumel spring (V2) and the Saint-Hippolyte sinkhole (V4) is particularly interesting. While $\left({ }^{228} \mathrm{Ra} /{ }^{226} \mathrm{Ra}\right)$ ratios increase from 0.81 to $1.06,\left({ }^{223} \mathrm{Ra} /{ }^{226} \mathrm{Ra}\right)$ ratios decrease from 0.116 to 0.088 . This evolution is likely due to progressive mixing of water derived from the basement, such as the water sampled in the Valestalière stream (VA), which has a high ${ }^{226} \mathrm{Ra}$ activity of $4.91 \mathrm{mBq} / \mathrm{L}$, a high $\left({ }^{228} \mathrm{Ra} /{ }^{226} \mathrm{Ra}\right)$ ratio $(1.41)$ and a low $\left({ }^{223} \mathrm{Ra} /{ }^{226} \mathrm{Ra}\right)$ ratio $(0.050)$. Indeed, when the four samples V2, V3 (V3a and V3b) and V4 are plotted together with the VA water sample, in a $\left({ }^{223} \mathrm{Ra} /{ }^{226} \mathrm{Ra}\right)-\left({ }^{228} \mathrm{Ra} /{ }^{226} \mathrm{Ra}\right)$ diagram (Fig. 5a), they define a good linear array that suggests mixing of these two types of water (water from the Liassic karst and water from the basement). This is confirmed by the $\left({ }^{228} \mathrm{Ra} /{ }^{226} \mathrm{Ra}\right)$ versus $1 /\left({ }^{226} \mathrm{Ra}\right)$ plot (Fig. 5b) which again shows a linear array of the data. Mass balance calculations based on ${ }^{226} \mathrm{Ra}$ activities suggest that only $10-20 \%$ of water from the basement, like the VA water, are needed to explain the data. We propose that the Valestalière river, which has a sinkhole when reaching the Mesozoic formations, contributes to the Vidourle water upstream of Saint-Hippolyte through its underground course. The outlet is most probably located in the Vidourle bed when the river crosses the Cévennes fault and when the Oxfordian marls of the SE compartment act as an impermeable barrier. The small proportion of the Valestalière contribution will have a minor influence on major ion concentrations. The fact that the $\mathrm{Ca}$ contents are similar to those of the Baumel spring is due to limestone dissolution during the underground course of the basement water largely undersaturated with respect 

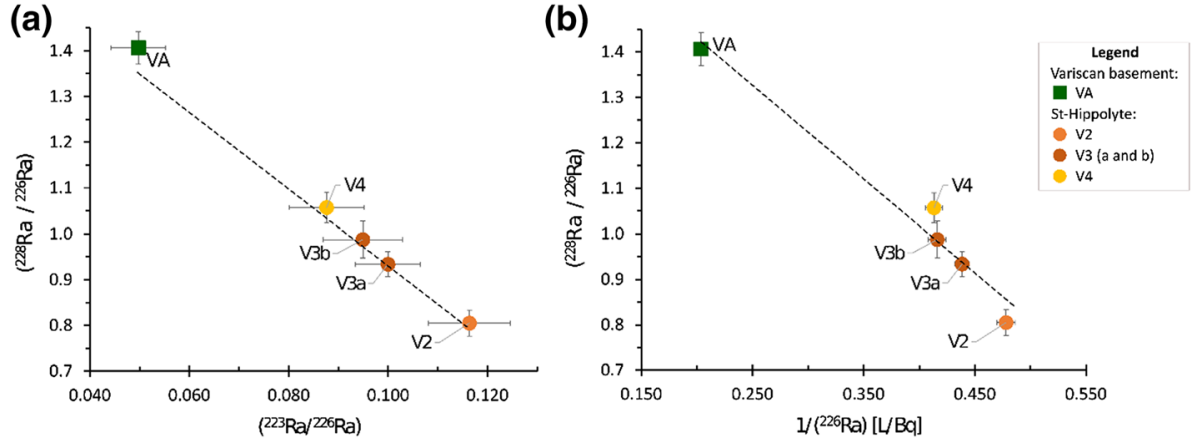

Fig. 5 a $\left({ }^{228} \mathrm{Ra} /{ }^{226} \mathrm{Ra}\right)$ versus $\left({ }^{223} \mathrm{Ra} /{ }^{226} \mathrm{Ra}\right)$ and $\mathbf{b}\left({ }^{228} \mathrm{Ra} /{ }^{226} \mathrm{Ra}\right)$ vs $1 /\left({ }^{226} \mathrm{Ra}\right)$ in water samples of BaumelSaint-Hippolyte-du-Fort section of the Vidourle river. The linear correlations are explained by mixing between the Valestalière water (VA), derived from the Variscan basement and the Baumel water (V2) (see text for further explanation). (For a colored view of the figure, the reader is referred to the web version of this article, same symbols in Figs. 2, 3, 4, 5)

to calcite. The linear relationship between $\left({ }^{223} \mathrm{Ra} /{ }^{226} \mathrm{Ra}\right)$ and $\left({ }^{228} \mathrm{Ra} /{ }^{226} \mathrm{Ra}\right)$ ratios (Fig. 5a) suggests that $\left({ }^{223} \mathrm{Ra} /{ }^{226} \mathrm{Ra}\right)$ ratios have not been affected by radioactive decay of ${ }^{223} \mathrm{Ra}$, i.e., that the underground water transfer has taken less than 2-3 days, for an estimated distance of about $3 \mathrm{~km}$. The calculated minimum flow rates $(40-60 \mathrm{~m} / \mathrm{h})$ are in agreement with those deduced from earlier artificial tracer experiments in this region (Drogue 1969).

\section{Conclusions}

In spite of their very low ${ }^{226} \mathrm{Ra}$ activities (from 1.5 to $4.9 \mathrm{mBq} / \mathrm{L}$ ), surface and groundwaters from the Upper Vidourle complex hydrosystem were successfully analyzed for all four natural $\mathrm{Ra}$ isotopes through gamma spectrometry. The data are compared to those of the previously studied Lez spring, which corresponds to a purely karstic hydrosystem.

The comparison between waters of the non-karstic (Variscan basement for the Vidourle upper course) and karstic part of the studied area (Mesozoic carbonates in the Vidourle downstream, and Lez spring) shows differences in ${ }^{226} \mathrm{Ra}$ activities and $\left({ }^{228} \mathrm{Ra} /{ }^{226} \mathrm{Ra}\right)$ ratios, which are both higher in waters draining the Variscan basement than in waters affected by dissolution of Mesozoic carbonates, in agreement with $\mathrm{Th} / \mathrm{U}$ ratios of both rock types. $\left({ }^{228} \mathrm{Ra} /{ }^{226} \mathrm{Ra}\right)$ ratios reported vs $1 /\left({ }^{226} \mathrm{Ra}\right)$ display linear relationships suggesting mixing of water components represented by the water from the basement (granites and schists), water from the Liassic dolomites and water from the Upper Jurassic/Lower Cretaceous limestones. Further South, the Lez spring waters are influenced by a deep mineralized water component, which could ultimately derive from paleo-seawaters that flooded the deep Mesozoic karst after the Messinian crisis. These mixing relationships based on Ra suggest that this element might have a more conservative behavior in this setting than usually assumed in freshwater, possibly due to the high water/rock ratio and flow rate in karst environment.

On a regional scale, $\left({ }^{228} \mathrm{Ra} /{ }^{226} \mathrm{Ra}\right)$ and ${ }^{87} \mathrm{Sr} /{ }^{86} \mathrm{Sr}$ ratios display a similar spatial distribution linked to the lithology of the drained rocks: a general decrease from North to South, resulting from an increased contribution of Mesozoic limestones toward the South. Our study demonstrates that $\left({ }^{228} \mathrm{Ra} /{ }^{226} \mathrm{Ra}\right)$ ratios can provide an additional tracer of the origin 
of underground water masses that is especially useful when a small proportion of water from the basement is involved in the mixing process.

Short-lived $\mathrm{Ra}$ isotopes are often in excess compared to their equilibrium values (with $\left({ }^{224} \mathrm{Ra} /{ }^{228} \mathrm{Ra}\right)$ and $\left({ }^{223} \mathrm{Ra} /{ }^{226} \mathrm{Ra}\right)$ ratios reaching 1.4 and 0.12 , respectively). Both short-lived nuclides are probably released in underground reservoirs from their insoluble adsorbed parents by alpha-recoil processes, in a similar way as ${ }^{222} \mathrm{Rn}$ is released from ${ }^{226} \mathrm{Ra}$-enriched solid grain surfaces. The presence of significant excesses of ${ }^{224} \mathrm{Ra}$ and ${ }^{223} \mathrm{Ra}$ in stream water is a good tracer of groundwater influx, in complement of the use of ${ }^{222} \mathrm{Rn}$, which can be affected by degassing.

${ }^{223} \mathrm{Ra}$ could be used to infer the transfer time of water on a timescale of several days, in the favorable case where the variation of the $\left({ }^{223} \mathrm{Ra} /{ }^{226} \mathrm{Ra}\right)$ ratio only results from ${ }^{223} \mathrm{Ra}$ decay, or when the effect of mixing with water having a different Ra-isotope signature can be corrected. Clearly, further detailed studies are needed to test this possibility. Nevertheless, we have shown that the mixing relationship evidenced upstream of St Hippolyte, on the basis of $\left({ }^{228} \mathrm{Ra} /{ }^{226} \mathrm{Ra}\right)$ ratios and ${ }^{226} \mathrm{Ra}$ activities, also holds for $\left({ }^{223} \mathrm{Ra} /{ }^{226} \mathrm{Ra}\right)$ ratios. This suggests the ${ }^{223} \mathrm{Ra}$ activities have not been modified by radioactive decay, implying minimum flow rates of 40 to $60 \mathrm{~m} / \mathrm{h}$ during the underground water transit.

Acknowledgements This work was supported by the Institutional Program for Scholarships Abroad for University Officials of the Office of International Affairs and External Cooperation (OAICE) of the University of Costa Rica (Grant Number OAICE-02-CAB-045-2014) and the Institut français d'Amérique centrale (IFAC) of the Ministère français des Affaires Etrangères et du Développement International (MAE-DI, grant number 789478C). We thank Sandra Van Exter for her help with major element analyses. We are grateful to the MEDYCYSS-OSU OREME team for making available their database. We thank T. Przylibski and an anonymous reviewer who made thoughtful comments and suggestions that helped to improve the manuscript.

\section{References}

Adams JAS, Osmond JK, Rogers JJW (1959) The geochemistry of thorium and uranium. Phys Chem Earth 3:298-348. https://doi.org/10.1016/0079-1946(59)90008-4

Baskaran M, Murphy DJ, Santschi PH, Orr JC, Schink DR (1993) A method for rapid in situ extraction and laboratory determination of $\mathrm{Th}, \mathrm{Pb}$, and $\mathrm{Ra}$ isotopes from large volumes of seawater. Deep Sea Res I 40(4):849-865

Baskaran M, Novell T, Nash K, Ruberg SA, Johengen T, Hawley N, Klump JV, Biddanda BA (2016) Tracing the seepage of subsurface sinkhole vent waters into lake Huron using radium and stable isotopes of oxygen and hydrogen. Aquat Geochem 22:349-374

Batiot-Guilhe C, Ladouche B, Seidel JL, Maréchal J-C (2013) Caractérisation hydrochimique et qualité des eaux de 1'aquifère karstique du Lez. Karstologia 62:23-32

Bicalho CC, Batiot-Guilhe C, Taupin JD, Patris N, Van Exter S, Jourde H (2019) A conceptual model for groundwater circulation using isotopes and geochemical tracers coupled with hydrodynamics: a case study of the Lez karst system, France. Chem Geol. https://doi.org/10.1016/j.chemgeo.2017.08.014

Blum JD, Erel Y, Brown K (1993) ${ }^{87} \mathrm{Sr} /{ }^{86} \mathrm{Sr}$ ratios of Sierra Nevada stream waters: implications for relative mineral weathering rates. Geochim Cosmochim Acta 57:5019-5025

Chabaux F, Riotte J, Dequincey O (2003) U-Th-Ra fractionation during weathering and river transport. In: Bourdon B, Henderson GM, Lundstrom CC, Turner SP (eds) Reviews in mineralogy and geochemistry: volume 52-Uranium-series geochemistry. The Mineralogical Society of America, Washington, pp 533-576

Chen JH, Edwards RL, Wasserburg GJ (1986) ${ }^{238} \mathrm{U},{ }^{234} \mathrm{U}$ and ${ }^{232} \mathrm{Th}$ in seawater. Earth Planet Sci Lett 80:241-251

Condomines M, Rihs S, Lloret E, Seidel JL (2010) Determination of the four natural Ra isotopes in thermal waters by gamma-ray spectrometry. Appl Radiat Isot 68:384-391. https://doi.org/10.1016/j.aprad iso.2009.10.056 
Drogue C (1969) Contribution à l'étude quantitative des systèmes hydrologiques karstiques d'après l'exemple de quelques karsts périméditerranéens. Thèse Doct. Sci. Nat., Université de Montpellier

Elliot T, Marcos D, Napier J (2014) Dissolved uranium, radium and radon evolution in the Continental Intercalaire aquifer, Algeria and Tunisia. J Environ Radioact 137:150-162. https://doi. org/10.1016/j.jenvrad.2014.07.003

Farrell JW, Clemens SC, Gromet LP (1995) Improved chronostratigraphic reference curve of late Neogene seawater $87 \mathrm{Sr} / 86 \mathrm{Sr}$. Geology 23:403-406

Gascoyne M (1992) Geochemistry of the actinides and their daughters. In: Ivanovich M, Harmon RS (eds) Uranium-series disequilibrium: applications to earth, marine, and environmental sciences. Oxford Science Publications, New York, pp 34-61

Guerrero JL, Vallejos Á, Cerón JC, Sánchez-Martos F, Pulido-Bosch A, Bolívar JP (2016) U-isotopes and ${ }^{226} \mathrm{Ra}$ as tracers of hydrogeochemical processes in carbonated karst aquifers from arid areas. J Environ Radioact 158-159:9-20. https://doi.org/10.1016/j.jenvrad.2016.03.015

Jones CE, Jenkins HC, Coe AL, Hesselbo SP (1994) Strontium isotopic variations in jurassic and cretaceous seawater. Geochim Cosmochim Acta 58:3061-3074

Kraemer TF (2005) Radium isotopes in Cayuga Lake, New York: indicators of inflow and mixing processes. Limnol Oceanog 50(1):158-168

Kraemer TF, Genereux DP (1998) Applications of uranium- and thorium-series radionuclides in catchment hydrology studies. In: Kendall C, McDonnell JJ (eds) Isotope tracers in catchment hydrology. Elsevier, New York, pp 679-722

Krishnaswami S, Cochran JK (2008) U-Th series nuclides in aquatic systems, vol 13. Elsevier, Amsterdam

Krishnaswami S, Graustein WC, Turekian KK, Dowd JF (1982) Radium, thorium and radioactive lead isotopes in groundwaters: application to the in situ determination of adsorption desorption rate constants and retardation factors. Water Resour Res 18:1663-1675. https://doi.org/10.1029/wr018i006p01663

Lamontagne S, Taylor AR, Herpich D, Hancock GJ (2015) Submarine groundwater discharge from the South Australian Limestone Coast region estimated using radium and salinity. J Environ Radioact 140:30-41. https://doi.org/10.1016/j.jenvrad.2014.10.013

Legeay PL (2013) Utilisation des isotopes du strontium pour caractériser les dynamiques de recharge et de transfert d'un aquifère karstique. unpublished M2 report, Université Pierre et Marie Curie, MinesParisTech \& AgroParisTech

Luís AT, Durães N, da Silva EF, Ribeiro S, Silva AJF, Patinha C, Almeida SFP, Azevedo MR (2019) Tracking multiple $\mathrm{Sr}$ sources through variations in ${ }^{87} \mathrm{Sr} /{ }^{86} \mathrm{Sr}$ ratios of surface waters from the Aljustrel massive sulphide mining area: geological versus anthropogenic inputs. Appl Geochem 102:108-120. https://doi.org/10.1016/j.apgeochem.2019.01.016

Molina Porras A, Condomines M, Seidel JL (2017a) Determination of low-level radium isotope activities in fresh waters by gamma spectrometry. Appl Radiat Isot 120:119-125. https://doi.org/10.1016/j. apradiso.2016.12.010

Molina-Porras A, Condomines M, Seidel JL (2017b) Radium isotopes, radon and ${ }^{210} \mathrm{~Pb}$ in karstic waters: example of the Lez system (South of France). Chem Geol 466:327-340. https://doi.org/10.1016/j. chemgeo.2017.06.022

Moore WS (1996) Large groundwater inputs to coastal waters revealed by ${ }^{226} \mathrm{Ra}$ enrichments. Nature 380(6575):612

Négrel P, Fouillac C, Brach M (1997) A strontium isotopic study of mineral and surface waters from the Cezallier (Massif Central, France): implications for mixing processes in areas of disseminated emergences of mineral waters. Chem Geol 135:89-101

Porcelli D (2008) Investigating groundwater processes using U- and Th-series nuclides. In: Krishnaswami S, Cochran JK (eds) U-Th series nuclides in aquatic systems. Elsevier, New York, pp 105153. https://doi.org/10.1016/s1569-4860(07)00004-6

Porcelli D, Swarzenski PW (2003) The behavior of U- and Th-series nuclides in groundwater. In: Bourdon B, Henderson GM, Lundstrom CC, Turner SP (eds) Reviews in mineralogy and geochemistry: volume 52-Uranium-series geochemistry. The Mineralogical Society of America, Washington, pp 317-361

Porcelli D, Kim CK, Martin P, Moore WS, Phaneuf M (2014). Properties of radium. In: IAEA technical report series 476-the environmental behaviour of radium: revised edition pp 6-32

Rodellas V, Garcia-Orellana J, Trezzi G, Masqué P, Stieglitz TC, Bokuniewicz H, Cochran JK, Berdalet E (2017) Using the radium quartet to quantify submarine groundwater discharge and porewater exchange. Geochim Cosmochim Acta 196:58-73. https://doi.org/10.1016/j.gca.2016.09.016

SANDRE (2012). Cours d'eau: Le Vidourle [WWW Document]. Jeux de données de référence. http:// www.sandre.eaufrance.fr/geo/CoursEau/Y34-0400. Accessed 6 March 17 
Shand P, Darbyshire DPF, Love AJ, Edmunds WM (2009) Sr isotopes in natural waters: applications to source characterisation and water-rock interaction in contrasting landscapes. Appl Geochem 24:574586. https://doi.org/10.1016/j.apgeochem.2008.12.011

Simler R (2014) Software diagrammes (V6.48). Laboratoire d'Hydrologie d'Avignon, Université d'Avignon et pays du Vaucluse, Avignon. http://www.lha.univ-avignon.fr/LHA-Logiciels.htm. Accessed 22 Nov 2014

Sturchio NC, Bohlke JK, Markun FJ (1993) Radium isotope geochemistry of thermal waters, Yellowstone National Park, Wyoming, USA. Geochim Cosmochim Acta 56:1203-1214

Vaute L, Drogue C, Garrelly L, Ghelfenstein M (1997) Relations between the structure of storage and the transport of chemical compounds in karstic aquifers. J Hydrol 199:221-238. https://doi.org/10.1016/ s0022-1694(96)03245-3

Vinson DS, Lundy JR, Dwyer GS, Vengosh A (2012) Implications of carbonate-like geochemical signatures in a sandstone aquifer: radium and strontium isotopes in the Cambrian Jordan aquifer (Minnesota, USA). Chem Geol 334:280-294. https://doi.org/10.1016/j.chemgeo.2012.10.030

Vinson DS, Lundy JR, Dwyer GS, Vengosh A (2018) Radium isotope response to aquifer storage and recovery in a sandstone aquifer. Appl Geochem. https://doi.org/10.1016/j.apgeochem.2018.01.006

Publisher's Note Springer Nature remains neutral with regard to jurisdictional claims in published maps and institutional affiliations. 